\title{
Two thymus-related autoimmune disorders: a case report and review of the literature
}

This article was published in the following Dove Press journal:

OncoTargets and Therapy

10 May 2014

Number of times this article has been viewed

\author{
Hanifeh Mirtavoos-Mahyari' \\ Adnan Khosravi² \\ Zahra Esfahani-Monfared' \\ Mohammad Behgam \\ Shadmehr ${ }^{3}$ \\ 'Chronic Respiratory Diseases \\ Research Center, National Research \\ Institute of Tuberculosis and Lung \\ Diseases (NRITLD), Shahid Beheshti \\ University of Medical Sciences, Tehran, \\ Iran; ${ }^{2}$ Tobacco Prevention and Control \\ Research Center, National Research \\ Institute of Tuberculosis and Lung \\ Diseases (NRITLD), Shahid Beheshti \\ University of Medical Sciences, Tehran, \\ Iran; ${ }^{3}$ Tracheal Diseases Research \\ Center, National Research Institute \\ of Tuberculosis and Lung Diseases \\ (NRITLD), Shahid Beheshti University \\ of Medical Sciences, \\ Tehran, Iran
}

Correspondence: Adnan Khosravi Hematology and Medical Oncology, Tobacco Prevention and Control Research Center, National Research Institute of Tuberculosis and Lung Diseases, Shahid Beheshti University of Medical Sciences, Shahid Bahonar Ave, Darabad, Tehran 19556, Iran Tel/Fax +98 21 2610 9946

Email adkhosravi@yahoo.com

\begin{abstract}
Thymoma is the most common tumor in the anterior mediastinum. A 56-year-old man presented unremitting and periodic chronic diarrhea of 9 weeks duration, and clinical examination revealed a huge nonhomogeneous mass lesion in the right lung and leukocytosis. He was treated with CHOP regimen (cyclophosphamide $1,200 \mathrm{mg} / \mathrm{m}^{2}$, doxorubicin $50 \mathrm{mg} / \mathrm{m}^{2}$, vincristine $1.5 \mathrm{mg} / \mathrm{m}^{2}$, and prednisolone $75 \mathrm{mg} / \mathrm{m}^{2} \times 5$ days) based on lung mass computed tomographyguided biopsy, but he was reevaluated because neither symptom improved. Surprisingly, celiac disease was documented with increased titer of immunoglobulin antibodies to gliadin and tissue transglutaminase. Lung mass rebiopsy and thymectomy demonstrated thymoma. After surgery, the patient showed aplastic anemia that responded well to cyclosporine. At 2-year follow-up, the patient's hematologic status and diarrhea were completely recovered and no symptom and/or sign of thymoma recurrence was seen.
\end{abstract}

Keywords: thymus, thymoma, celiac, aplastic anemia, autoimmune disorder

\section{Introduction}

Thymoma is the most common tumor in the anterior mediastinum ${ }^{1}$ and originates from thymus epithelial cells. ${ }^{2}$ It seems that paraneoplastic syndromes associated with thymoma have an underling autoimmune characterization. ${ }^{3}$ Here we describe a patient with thymoma who complained of multiple paraneoplastic diseases occurring in sequence before and after the treatment of the tumor.

\section{Case report}

A 56-year-old man presented (February 2008) with unremitting and periodic chronic diarrhea of 9 weeks duration and with a huge nonhomogeneous mass lesion in the right lung, with aorta and chest wall involvement and minimal right side pleural effusion (Figure 1 and 2). Stool exam was completely normal and testing to measure amount of stool fat was unremarkable. Physical examination was normal. No significant abnormalities were detected in the routine serum biochemistry, immunology studies, and complete blood count, except for leukocytosis (white blood cells $=17,810 \mathrm{cell} / \mathrm{s} / \mu 1$, neutrophils $=15 \%$, lymphocytes $=76 \%$ ). All rheumatologic tests were normal (urinalysis, collected 24-hour urine for calculation of creatinine, quantities of proteinuria and protein/creatinine ratios, antinuclear antibodies, anti-double stranded DNA, antiphospholide antibody, anti-Smith antibodies, and C3 and C4). Rectosigmoidescopy revealed only slight inflammation of mucosa. Computed tomography-guided biopsy of the right lung mass revealed pulmonary involvement by lymphoid neoplasm, T-cell type (immunohistochemistry was positive for leukocyte common antigen and CD3). 
The patient received two cycles of chemotherapy with CHOP regimen (cyclophosphamide 1,200 $\mathrm{mg} / \mathrm{m}^{2}$, doxorubicin 50 $\mathrm{mg} / \mathrm{m}^{2}$, vincristine $1.5 \mathrm{mg} / \mathrm{m}^{2}$, and prednisolone $75 \mathrm{mg} / \mathrm{m}^{2}$; for 5 days). ${ }^{4}$ At the end of the second course of treatment, there was no change in objective or subjective responses, and diarrhea had not ceased. To confirm the diagnosis, he was completely reevaluated. Rectosigmoidescopy this time showed congestion of rectum, sigmoid, descending colon, splenic flexure, and transverse colon. Stool examination showed occult blood $2+$, and serologic serum immunoglobu$\operatorname{lin}(\mathrm{Ig}) \mathrm{A}$ was $647 \mathrm{mg} / \mathrm{dl}$ and both serum IgA-class tissue transglutaminase (tTG) and Ig anti-gliadin demonstrated increased titer (IgA enzyme immuno assay (EIA): >300 U/ $\mathrm{ml}$ ) and celiac disease was concluded, but duodenal biopsy was not performed. The patient was advised to follow a gluten-free diet. Right lung mass rebiopsy was performed, and surprisingly the pathologic exam revealed thymoma, type B2 according to the World Health Organization classification ${ }^{5}$. Finally, the lesion was radically resected through a median sternotomy and was determined by the Masaoka system to be stage IIB according to surgical findings. Two weeks after thymectomy, the patient showed the following laboratory values: platelet count of $7 \times 10^{3} / \mu \mathrm{L}$ and hemoglobin concentration of $8.6 \mathrm{~g} / \mathrm{dL}$. Bone marrow aspiration and biopsy was compatible with a marked decrease in erythrocytes and megakaryocytes. We treated the patient with cyclosporine $300 \mathrm{mg} /$ day, and at 2-year follow-up, the patient's hematologic status and diarrhea were completely recovered and no symptom and/or sign of thymoma recurrence was seen. Repeat computed tomography scanning of the thorax showed no evidence of thymoma relapse.

\section{Discussion}

Many autoimmune phenomena have been reported in relation with thymoma, proposing an immunopathological association between thymoma and autoimmune disease. ${ }^{6,7}$ As the site of maturation for T-(CD4+ and CD8) cells, the thymus plays a central role in adaptive immunity, and it can produce the autoreactive T-cell clones that are responsible for autoimmune disease. ${ }^{8,9}$ It seems that thymoma may trigger either a unique immune tolerance defect (especially in myasthenia gravis and the cytopenias) or a general disturbance of immune regulation.

The list of autoimmune diseases associated with thymoma is long, ${ }^{6}$ and some believe that this relation occurs more often with thymoma than with any other human tumors. ${ }^{7}$ In our patient, thymoma was associated with various autoimmune diseases involving the gastrointestinal tract, red blood cells, and platelets.
Celiac disease is produced by a reaction to gluten, a storage protein found in wheat, and similar substances. ${ }^{10}$ The prevalence of autoimmune diseases and malignancy is increased in celiac disease patients. ${ }^{1-14}$ When intestinal cells are exposed to gluten, the enzyme tTG modifies the protein, and the immune response activates $\mathrm{T}$ lymphocytes to initiate the autoimmune process against the intestinal tissue, causing an inflammatory reaction. tTG is the known target in celiac disease, deaminating gliadin peptide, leading to increased presentation to T-cells, and thereby stimulating the immune system. ${ }^{10}$ Some studies reported autoimmune enteropathy in association with thymoma, but there are few studies addressing the association of celiac disease and thymoma. ${ }^{15,16}$ Also, association between aplastic anemia and

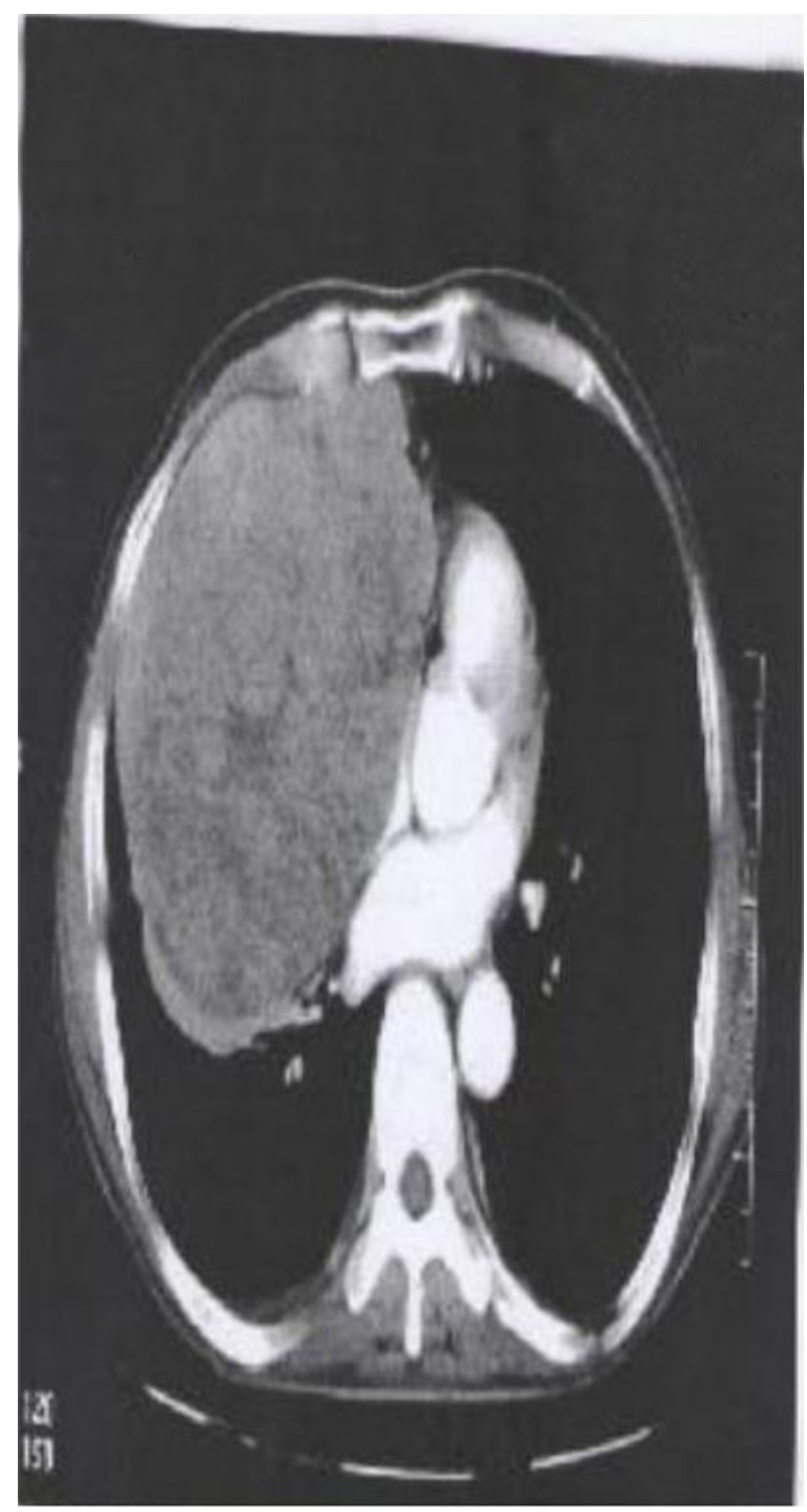

Figure I Nonhomogeneous mass lesion was located in the right lung. 


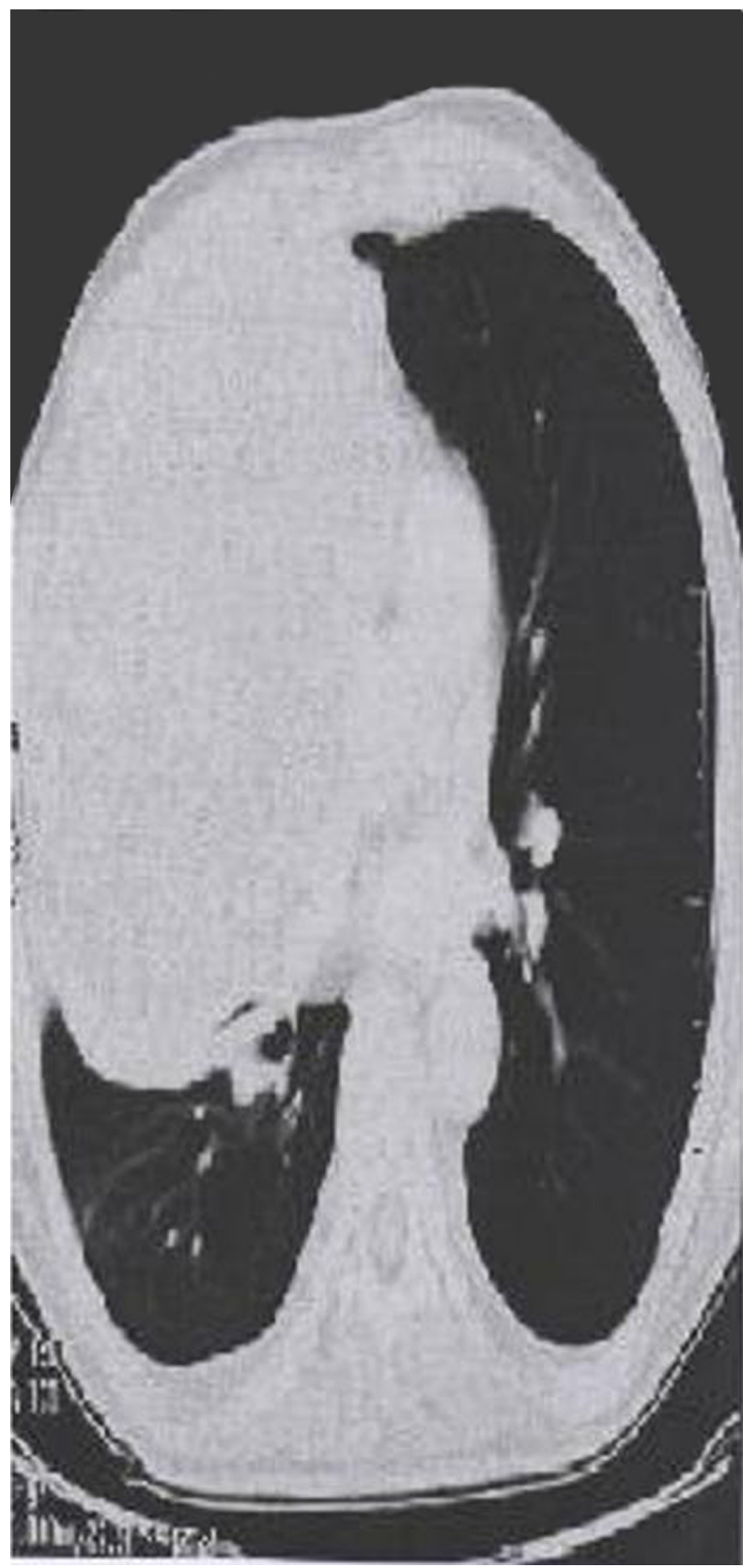

Figure 2 Mass lesion was located in the right lung.

celiac disease have rarely been reported, and it is supposed that this relation to share an underlying immune pathological mechanism that destroys tissue with T-cell mediation. . $^{13,14,17}$ It is important to know that a gluten-free diet is protective against the development of malignancy during celiac disease. ${ }^{13}$ Immunophenotyping of peripheral blood T-cells expressing T-cell receptor $\gamma \beta$ discriminated celiac disease from autoimmune enteropathy, which commonly expresses T-cell receptor $\alpha \beta .^{18}$ Megakaryocytic hypoplasia has been reported after resection of a thymoma in previous studies, ${ }^{2,19}$ and the association of thymoma with pure red cell aplasia is well known. ${ }^{20}$ Amegakaryocytic thrombocytopenia following thymoma may represent an early presentation of impending aplastic anemia, with the time interval between thymoma resection and development of aplastic anemia between 3 and 48 months. ${ }^{2,21}$ Aplastic anemia may be related with active thymoma or with thymoma in remission. ${ }^{22}$ Our case showed anemia and thrombocytopenia with megakaryocytic hypoplasia 2 weeks after thymectomy, presenting symptoms of aplastic anemia. In the present case, aplastic anemia responded very well to cyclosporine, and hemoglobin and platelet recovery reached transfusion-independence by day 24 and day 27, respectively. Successful treatment with cyclosporine suggests an immunologic mechanism for this disorder. The thymus may make autoreactive $\mathrm{T}$ lymphocytes against stem cells, erythroid precursors, and megakaryocyte precursors. $^{2}$

On the whole, association between aplastic anemia and other autoimmune disease such as thymoma or celiac disease with autoimmune disease have rarely been reported, and in our case, it appears that these three diseases were linked in our case.

\section{Conclusion}

An interesting aspect of this case report may be that different paraneoplastic and autoimmune manifestation onset at different times and in sequence; this supports the hypothesis that an underlying autoimmune mechanism could have been in operation. It is advisable for clinicians to exclude thymomarelated syndromes in patients with thymoma diagnosis.

\section{Disclosure}

The authors report no conflicts of interest in this work.

\section{References}

1. Singh G, Rumende CM, Amin Z. Thymoma: diagnosis and treatment. Acta Med Indones. 2011;43(1):74-78.

2. Maslovsky I, Gefel D, Uriev L, Ben Dor D, Lugassy G. Malignant thymoma complicated by amegakaryocytic thrombocytopenic purpura. Eur J Intern Med. 2005;16(7):523-524.

3. Lucchi M, Viti A, Ricciardi R, Murri L, Mussi A. Four thymus-related syndromes in a case of invasive thymoma. J Thorac Cardiovasc Surg. 2007;134(5):1376-1378.

4. Fisher RI, Gaynor ER, Dahlberg S, et al. Comparison of a standard regimen (CHOP) with three intensive chemotherapy regimens for advanced non-Hodgkin's lymphoma. N Engl J Med. 1993;328(14): 1002-1006.

5. Rosai J, Sobin L. Histological typing of tumors of the thymus. In: Rosai J, Sobin L, editors. World Health Orgnanization, International Classification of tumors. Berlin: Springer; 1999. 9-14.

6. Fletcher AL, Calder A, Hince MN, Boyd RL, Chidgey AP. The contribution of thymic stromal abnormalities to autoimmune disease. Crit Rev Immunol. 2011;31(3):171-187.

7. Marx A, Hohenberger P, Hoffmann H, et al. The autoimmune regulator AIRE in thymoma biology: autoimmunity and beyond. J Thorac Oncol. 2010;5(10 Suppl 4):S266-S272. 
8. Müller-Hermelink HK, Marx A. Thymoma. Curr Opin Oncol. 2000;12(5):426-433.

9. Buckley C, Douek D, Newsom-Davis J, Vincent A, Willcox N. Mature, long-lived CD4+ and CD8+ T cells are generated by the thymoma in myasthenia gravis. Ann Neurol. 2001;50(1):64-72.

10. Di Sabatino A, Corazza GR. Coeliac disease. Lancet. 2009;373(9673): 1480-1493.

11. Freeman HJ, Chopra A, Clandinin MT, Thomson AB. Recent advances in celiac disease. World J Gastroenterol. 2011;17(18): 2259-2272.

12. Kister I, Gulati S, Boz C, et al. Neuromyelitis optica in patients with myasthenia gravis who underwent thymectomy. Arch Neurol. 2006;63(6):851-856.

13. Holmes GK, Prior P, Lane MR, Pope D, Allan RN. Malignancy in coeliac disease - effect of a gluten free diet. Gut. 1989;30(3):333-338.

14. Green PH, Fleischauer AT, Bhagat G, Goyal R, Jabri B, Neugut AI. Risk of malignancy in patients with celiac disease. Am J Med. 2003;115(3):191-195.

15. Marx A, Schultz A, Wilisch A, Helmreich M, Nenninger R, MüllerHermelink HK. Paraneoplastic autoimmunity in thymus tumors. Dev Immunol. 1998;6(1-2):129-140.
16. Mais DD, Mulhall BP, Adolphson KR, Yamamoto K. Thymomaassociated autoimmune enteropathy. A report of two cases. Am J Clin Pathol. 1999;112(6):810-815.

17. Salmeron G, Patey N, de Latour RP, et al. Coeliac disease and aplastic anemia: a specific entity? Br J Haematol. 2009;146(1):122-124.

18. Elwing JE, Clouse RE. Adult-onset autoimmune enteropathy in the setting of thymoma successfully treated with infliximab. Dig Dis Sci. 2005;50(5):928-932.

19. Chen J, Yang Y, Zhu D, et al. Thymoma with pure red cell aplasia and Good's syndrome. Ann Thorac Surg. 2011;91(5):1620-1622.

20. Cho AR, Cha YJ, Kim HR, Park EK, Cha EJ. [Acquired amegakaryocytic thrombocytopenia after thymectomy in a case of pure red cell aplasia associated with thymoma]. Korean J Lab Med. 2010;30(3):244-248. Korean.

21. Takeuchi Y, Fujii Y, Okumura M, Inada K, Nakahara K, Matsuda H. Accumulation of immature CD3-CD4+CD8- single-positive cells that lack CD69 in epithelial cell tumors of the human thymus. Cell Immunol. 1995;161(2):181-187.

22. Ritchie DS, Underhill C, Grigg AP. Aplastic anemia as a late complication of thymoma in remission. Eur J Haematol. 2002;68(6): 389-391.
OncoTargets and Therapy

\section{Publish your work in this journal}

OncoTargets and Therapy is an international, peer-reviewed, open access journal focusing on the pathological basis of all cancers, potential targets for therapy and treatment protocols employed to improve the management of cancer patients. The journal also focuses on the impact of management programs and new therapeutic agents and protocols on

\section{Dovepress}

patient perspectives such as quality of life, adherence and satisfaction. The manuscript management system is completely online and includes a very quick and fair peer-review system, which is all easy to use. Visit http://www.dovepress.com/testimonials.php to read real quotes from published authors. 